\section{En god kroppsdoktor er det viktigste}

Ingrid Netelands beretning om den personlige opplevelsen i Tidsskriftet nr. 12-13/2013 er absolutt egnet til å gi aha-opplevelser (1), men jeg har noen innspill. For det første: Vil de som fra pasientens ståsted kunne hatt mest nytte av artikkelen lese den? Jeg selv har også en del gode refleksjoner jeg ikke evner å realisere i praksis, og de fleste burde nok arbeide mer med seg selv. For det andre: artikkelen fremstiller pasienten som naiv. Dette tror jeg ikke artikkelforfatteren er alene om. Leger, som regel meget tidlig modne og veltilpassede mennesker, gjør kommunikasjonen med pasienten noe enkel for seg selv ved å oppfatte pasienter slik. En stadig større andel av befolkningen har begrunnede synspunkter på livet, både når det gjelder de kroppslige og åndelige dimensjoner. Dette mener jeg bør være legens forutsetning, ikke den naive og ubehjelpelige lidende. Til slutt vil jeg stille spørsmålet om legene er så mye flinkere som kroppsdoktorer enn som samtalepartnere? Innenfor kroppsmedisinen forutsetter man at det ikke skjer feil.

Feil oppstår ikke bare av travelhet, manglende sekretærer og halvgode dataløsninger. Bare i løpet av det siste året kjenner jeg til to dødsfall der leger som har vært nære pårørende, særdeles kompetente sådanne, innså at kollegene ikke hadde vært absolutt på høyden. Med den livserfaringen en lege har, burde kanskje ambisjonen være mer beskjeden enn å skulle praktisere som et helt menneske. For eksempel å være på vei til å bli et helt menneske og for øvrig opprettholde en profesjonell standard? Jeg vil håpe at pasienter og leger tar del i det samme menneskeverdet, kroppslig og sjelelig. Men vi er altså alle «under construction».

\section{Jamil Dybwad \\ jdybwad@online.no}

Jamil Dybwad (f. 1954) er rådgiver innen miljøsertifisering Ingen oppgitte interessekonflikter.

Litteratur

1. Neteland I. Hvor er du? Tidsskr Nor Legeforen 2013; 133: 1340-1.

Dette er en redigert versjon av et innlegg publisert som rask respons på nett 18.6. 2013. http://tidsskriftet.no/article/3029493/

\section{Spekter har aldri sagt annenhver helg}

I sin «god sommer»-artikkel i Tidsskriftet nr. 12-13/2013 hevder legepresident Hege Gjessing at Spekter kjemper en kamp for at sykepleierne skal jobbe annenhver helg (1). Her har Gjessing misforstått $i$ betydelig grad. Hun sprer derfor feilaktig informasjon om hva arbeidsgiversiden i helseforetakene står for.

Spekter har aldri tatt til orde for at sykepleiere eller andre skal jobbe annenhver helg. Tvert imot har vi understreket $i$ debatten at vi forstår godt at verken sykepleiere eller andre ønsker å arbeide hyppigere enn tredjehver helg. Imidlertid skal det være like god kvalitet på pasientbehandlingen i helgene som i ukedagene. Vi må derfor finne tiltak som sikrer både best mulig fordeling av helgebelastningen og en forsvarlig bemanning også i helgene. Hver fjerde sykepleier i sykehusene arbeider ikke helg i det hele tatt. Hadde helgearbeidet også blitt fordelt på disse, er det ikke sikkert man trenger å øke helgebelastningen i noen særlig grad for dem som allerede jobber helg.

Videre er det grundig dokumentert gjennom blant annet skift/ turnusutvalget, ledet av professor Steinar Holden, at løsningene på problemet med ufrivillig deltid ligger i organiseringen av helgearbeidet.

Gjessing sier om Spekters standpunkt i helsedebatten at «jeg kan ikke tenke meg noe annet enn at det kun ville føre til at flere velger å jobbe deltid». I Spekter baserer vi politikken vår på fakta. Statistisk sentralbyrå har allerede kartlagt fakta om deltid for oss.
I arbeidskraftsundersøkelsen 2010 svarer for eksempel 10\% av sykepleierne at de jobber deltid fordi arbeidet er for krevende, $10 \%$ er for syke, $20 \%$ får ikke heltid og $20 \%$ har små barn. $40 \%$ angir imidlertid ingen spesiell årsak for sitt deltidsvalg.

I en undersøkelse Norstat gjorde for Spekter i 2011, sier omtrent halvparten av norske kvinner at de ville ha jobbet mer dersom arbeidstiden var mer tilpasset individuelle behov. Dette er vanskelig å få til i dagens arbeidstidssystem. I Spekters arbeidsgiverbarometer 2013, som er utført av analysebyrået Opinion Perduco, kommer det frem at hele $97 \%$ av helselederne er uenig i at arbeidstidsbestemmelsene er godt tilpasset dagens arbeidsliv (2).

Jeg registrerer at Gjessing oppfatter Spekters arbeidstidspolitikk som en trussel mot trepartssamarbeidet. Det er vanskelig å forstå at ulike meninger om en sak skal være en trussel mot samarbeid. I den norske modellen tåler vi meningsforskjeller når vi diskuterer utfordringer i velferds- og arbeidslivspolitikken. Derimot vil jeg peke på at feilinformering og omskrivning av andres synspunkt kan virke begrensende for samhandling og dialog.

Spekter er alltid åpen for konstruktive prosesser med arbeidstakerorganisasjonene om hvordan vi kan sikre helsetjenester i verdensklasse også i fremtiden. En grunnleggende forutsetning for ethvert godt samarbeid er faglige og faktabaserte diskusjonerikke personangrep og forvrengning av motpartens meninger.

\section{Anne-Kari Bratten \\ post@spekter.no \\ Anne-Kari Bratten (f. 1964) er administrerende direktør i Arbeidsgiver- foreningen Spekter. \\ Ingen oppgitte interessekonflikter.}

\section{Litteratur \\ 1. Gjessing H. God sommer! Tidsskr Nor Legeforen 2013; 133: 1401. \\ 2. Spekters arbeidsgiverbarometer 2013. http://spekter.no/Global/Rapporter/ Egne_rapporter/SPEKTER-\%2346940-v1-Arbeidsgiverbarometeret_2013.PDF (4.7.2013).}

Dette er en redigert versjon av et innlegg publisert som rask respons på nett 4.7.2013. http://tidsskriftet.no/article/3031243/

\section{H. Gjessing svarer:}

Spekter har lest og tatt seg tid til å kommentere min leder i nr. 12/2013. Det er bra. Mitt viktigste budskap i denne lederen er å peke på det ansvaret vi som parter har for samarbeid om oppgavene i sykehus. Hvilken arbeidspolicy som velges, har sammenheng med ideologi. Vi tror sterkt på at god ledelse, dialog og samarbeid gir det beste grunnlaget for utvikling, vekst og godt arbeidsmiljø. Jeg er enig i at «mer enn tredjehver helg» er mer presist enn «annenhver helg», men innholdet i dette kravet fra Spekter er ikke det sentrale i lederen.

I en stadig mer kompleks sykehushverdag med høy omstillingsaktivitet og mange pasientbehandlinger må vi satse på ledere som gis tillit til å ta ansvar for drift og utvikling av avdelinger og sykehus i tett og godt samarbeid med ansatte. Det betyr i praksis lokale ordninger og avtaler som løser de utfordringene det enkelte sykehus har. Dette gir positive ringvirkninger i motsetning til retorisk press og makt. Legeforeningen skal være en premissleverandør i arbeidet med å styrke kunnskapen hos ledere og tillitsvalgte om hvordan godt samarbeidsklima kan oppnås. Flere enn oss må bidra til at ledere og ansatte får tid, handlingsrom og kunnskap til å kunne ta dette ansvaret. Med samarbeid oppnås langt mer enn ved styring, og samarbeidet må bygge på tillit.

Vi ønsker et arbeidsklima i sykehus som gjør at ledere og ansatte sammen finner gode løsninger for sykehusdriften der de er - løsninger som kan variere mellom sykehus og avdelinger. Uenigheter og konflikter bør løses på lavest mulig nivå. Vi har omgjort tillitsvalgtopplæringen vår til å hete Fra tillitsvalgt til leder. Denne høsten starter vi et nytt kurstilbud til ledere i sykehus, og vi tror 
det blir veldig bra. Våre høye ambisjoner når det gjelder å investere i sykehusledere kommer også til uttrykk gjennom vår årlige dialogkonferanse, der vi deler ut pris til årets legeleder.

Hege Gjessing

hege.gjessing@legeforeningen.no

Hege Gjessing (f. 1972) er president i Den norske legeforening. Ingen oppgitte interessekonflikter.

\section{Hvor stor er effekten av intervensjon?}

Rune J. Ulvik forklarer i Tidsskriftet nr. 12-13/2013 om hemoglobin at testen ikke sier noe om størrelsen på endringene, men «beregner sannsynligheten for at økning i hemoglobin hos deltakerne i gruppen er tilfeldig» (1). Etter mitt skjønn må det bety at endringen er statistisk signifikant. Ulvik og medarbeideres studie tar verken hensyn til biologisk eller analytisk variasjon og dokumenterer på ingen måte at kosttilskudd med jern optimaliserer hemoglobinnivå (2). Endringen som studien viser til (Median Hb-verdi økte med 0,4 g/100 ml i samme gruppe), kan til og med ligge innenfor både den biologiske og analytiske variasjonen.

Jeg ønsker med dette å sitere Arild Bjørndal \& Dag Hofoss (3): «Statistisk signifikans er ikke det samme som klinisk relevans. Er det mange nok personer i utvalgene, vil selv klinisk betydningsløse forskjeller bli signifikante. Den gode læresetning som illustrerer dette lyder: A difference is a difference only if it makes a difference.»

\section{Krystyna Sandvik}

krystyna.sandvik@gmail.com

Krystyna Sandvik (f. 1959) er bioingeniør ved Avdeling for medisinsk biokjemi, Oslo universitetssykehus, Rikshospitalet.

Ingen oppgitte interessekonflikter.

\footnotetext{
Litteratur

1. Ulvik RJ. Akuttfaseprotein og/eller jernlager. Tilsvar. Tidsskr Nor Legeforen 2013; 133: 1285

2. Ulvik RJ, Møller R, Hervig T. Kosttilskudd med jern ved jernmangel. Tidsskr Nor Legeforen 2013; 133: 845-9.

3. Bjørndal A, Hofoss D. Statistikk for helse og sosialfagene. Oslo: Gyldendal, 2010.
}

Dette er en redigert versjon av et innlegg publisert som rask respons på nett 11.7.2013. http://tidsskriftet.no/article/3026672/

\section{R. Ulvik svarer:}

Sandvik er skeptisk til at økningen i median hemoglobinverdi innen gruppene er reell etter jernbehandling. Nullhypotesen - ingen forskjell på medianverdien før og etter behandling med signifikansgrense $\mathrm{p}=0,013$ - ble forkastet da sannsynligheten for å få en medianverdi etter behandling som var minst like stor som den vi faktisk fikk, gitt at nullhypotesen var sann, var $<0,1 \%$ i lavdosegruppen og 0,5\% i høydosegruppen (1).

Nullhypotesen ble testet med Wilcoxon signed-rank test som beregner p-verdien på basis av hvor mange individer som i en senere måling får en endret analyseverdi sammenliknet med utgangsverdien, uavhengig av verdiens størrelse. Sandvik mener at man må ta hensyn til intraindividuell biologisk og analytisk variasjon, og ved å anvende disse variasjonskoeffisientene på forskjellen i medianverdien før og etter behandling, finner hun at økningen ikke er statistisk signifikant. Men intraindividuell biologisk variasjon er, sammen med analytisk variasjon, et uttrykk for usikkerheten i et enkelt prøvesvar, ikke for variasjonen i en medianverdi som avhenger av interindividuell biologisk variasjon.

Som påpekt av Sandvik kan selv en liten og ubetydelig klinisk forskjell bli statistisk signifikant dersom antallet i forsøksgruppene er stort nok (2). I vår studie var det, til tross for et relativt lavt antall deltakere i gruppene, statistisk signifikant effekt av behandlingen.

Sandvik har rett $i$ at klinisk relevans ikke er det samme som statistisk signifikans. Skal man bedømme den kliniske relevansen av hemoglobinøkningen innen gruppen, må man ta hensyn til at andelen individer med lett anemi var lav, henholdsvis $15 \%$ og $22 \%$ i lavdose- og høydosegruppen. De fleste studiedeltakerne hadde jernmangel uten anemi. Det var derfor ikke forventet at en eventuell økning i hemoglobin ville bli særlig stor ved jerntilskudd, verken på individ- eller gruppenivå. I diskusjonen gikk vi grundig inn på det fysiologiske grunnlaget for hvor mye jern som må tilføres for å korrigere en lett nedsatt erytropoese, og vi begrunnet at lavdosejern var tilstrekkelig for å øke hemoglobinverdien med rundt $0,5 \mathrm{~g} / 100 \mathrm{ml}$. Derfor mener vi at våre funn har klinisk interesse både når det gjelder individuell behandling av lett jernmangelanemi og ved det faktum at man oppnår samme resultat med en lav som ved en tradisjonell høy jerndose.

\section{Rune Ulvik}

rune.ulvik@med.uib.no

Rune Ulvik (f. 1947) er professor ved Klinisk institutt 2, Det medisinskodontologiske fakultet, Universitetet i Bergen.

Oppgitte interessekonflikter: Forfatter har fått dekket reiseutgifter Bergen-Oslo tur-retur fra Cederroth AS i juni 2013 i forbindelse med deltakelse i et TV-program om temaet jernmangel.

Litteratur

1. Samuelsen CH. Riktig definisjon av p-verdi? Tidsskr Nor Legeforen 2013; 133: 500.

2. Skovlund E. Spør først, regn siden. Tidsskr Nor Legeforen 2013; 133: 10 .

\section{Nye diagnosesystemer - ny virkelighet?}

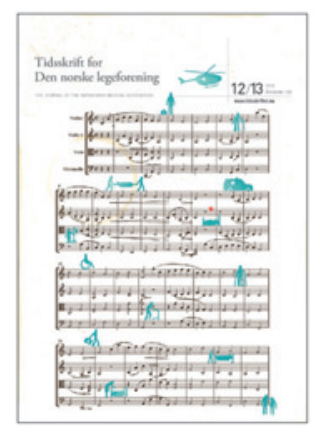

I Tidsskriftet nr. 12-13/2013 skrev Anne Høye en fin artikkel som viste med all ønskelig tydelighet hvordan diagnosekulturen har utviklet seg og blitt misbrukt (1). I dagens helsevesen, og kanskje særlig i sykehus, der økonomien er så styrende og diagnosen utløser pengene, er dette er et viktig dokument. Det er helt grunnleggende kunnskap å kjenne til hva en diagnose i de forskjellige psykiatriske klassifikasjonssystemene egentlig er. De er ikke noe uproblematisk speil av virkeligheten der ute! Til tross for det, blir de ulike kategoriene i de diagnostiske systemene behandlet som separate sykdommer som finnes i virkeligheten: Det det gjelder er å finne den rette. Skjemadiagnostikerne med sine avkryssingsteknikker har en tendens til å utvide diagnoser i de tilfeller der det ikke finnes eksakte kriterier, eller der det er overlapping av «tilstander». Det farlige er jo at menneskenes egentlige behov blir fullstendig oversett. Det har kommet flere og flere ikke-medisinere som ledere ved klinikkene, og lederen kan få stor innflytelse på hva behandlingen skal konsentreres om. Når diagnosesystemene blir styrende for både den økonomiske kontrollen og den medisinske/psykologiske behandlingen, er det virkelig fare på ferde.

Hvordan få gjennomslag i klinisk praksis for det denne artikkelen omhandler? Det er vel og bra med et nytt system, men de «gamle» diagnosene stemmer for godt overens med den folkelige forestillingen om at det finnes en riktig diagnose et sted. Det kan bli en rent akademisk forbedring, men vil den nye tenkningen gjennomsyre systemet slik at menneskene får hjelp? Hvordan få ledere til å lære dette? Hvordan får vi krav til utdanning hos lederne, ikke bare i skjemadiagnostikk, men også i grunnlagstenkning? Jeg vil virkelig utfordre både artikkelforfatteren, som skal ha all mulig 